\title{
Reply to the letter by Yang et al. RE: acute myeloid leukemia associated with FGFR1 abnormalities
}

\author{
Yonggoo Kim $\cdot$ Hyeyoung Lee $\cdot$ Myungshin Kim
}

Received: 10 May 2013/Revised: 22 May 2013/Accepted: 28 May 2013/Published online: 5 June 2013

(c) The Japanese Society of Hematology 2013

\section{To the Editor}

We would like to thank for Yang and his colleagues' insightful comments on our work. In our previous manuscript, we described three cases of $8 \mathrm{p} 11$ myeloproliferative syndrome (EMS) that initially presented as acute myeloid leukemia (AML). Two of these- $t(8 ; 13)(\mathrm{p} 11.2 ; \mathrm{q} 12)$ and $\mathrm{t}(8 ; 9)(\mathrm{p} 11.2 ; \mathrm{q} 33)$-were cytogenetically identified, but one with variant $\operatorname{inv}(8)(\mathrm{p} 11.2 \mathrm{q} 13)$ was detected only by fluorescence in situ hybridization (FISH) [1]. A number of other EMS cases presenting as AML have been reported, and new therapeutic strategies are being introduced [2-4]. Many EMS cases are initially recognized by conventional cytogenetics. FISH can confirm the majority of EMS and determine submicroscopic deletions, but in a few cases did not detect the rearrangement [5]. Identification and characterization of fusion genes are clinically important to the understanding of disease pathogenesis and selection of the monitoring method [3]. FISH using home-brew probes and $5^{\prime}$ rapid amplification of cDNA end PCR with sequences analysis have been used [6,7]. Long-distance PCR and long-distance inverse PCR were introduced in a previous report as diagnostic tools capable of identifying the corresponding partner genes of FGFRI [8].

Clearly, international collaborative studies, including distinct ethnic entities, aimed at elucidating poorly understood aspects of EMS such as incidence, clinical and laboratory manifestation, genetic aberrations including submicroscopic deletion and their association with pathogenesis and prognosis, are warranted.

\section{References}

1. Lee H, Kim M, Lim J, Kim Y, Han K, Cho BS, Kim HJ. Acute myeloid leukemia associated with FGFR1 abnormalities. Int $\mathbf{J}$ Hematol. 2013 Apr 23 [Epub ahead of print]. doi:10.1007/ s12185-013-1337-5.

2. Matikas A, Tzannou I, Oikonomopoulou D, Bakiri M. A case of acute myelogenous leukaemia characterised by the BCR-FGFR1 translocation. BMJ Case Rep. 2013 Mar 20 [Epub ahead of print]. doi:10.1136/bcr-2013-008834.

3. Yamamoto S, Ebihara Y, Mochizuki S, Kawakita T, Kato S, Ooi J, et al. Quantitative polymerase chain reaction detection of CEP110FGFR1 fusion gene in a patient with 8 p11 myeloproliferative syndrome. Leuk Lymphoma. 2013 Feb 16 [Epub ahead of print]. doi:10.3109/10428194.2013.767455.

4. Morishige S, Oku E, Takata Y, Kimura Y, Arakawa F, Seki R, et al. A case of $8 \mathrm{p} 11$ myeloproliferative syndrome with BCRFGFR1 gene fusion presenting with trilineage acute leukemia/ lymphoma, successfully treated by cord blood transplantation. Acta Haematol. 2013;129:83-9.

5. Yoshida C, Takeuchi M, Sadahira Y. A novel $t(1 ; 8)(\mathrm{q} 25 ; \mathrm{p} 11.2)$ translocation associated with $8 \mathrm{p} 11$ myeloproliferative syndrome. Br J Haematol. 2012;156:271-3.

6. Wasag B, Lierman E, Meeus P, Cools J, Vandenberghe P. The kinase inhibitor TKI258 is active against the novel CUX1-FGFR1 fusion detected in a patient with T-lymphoblastic leukemia/ lymphoma and t(7;8)(q22;p11). Haematologica. 2011;96:922-6.

7. Li F, Zhai YP, Tang YM, Wang LP, Wan PJ. Identification of a novel partner gene, TPR, fused to FGFR1 in 8p11 myeloproliferative syndrome. Genes Chromosomes Cancer. 2012;51:890-7.

8. Yang JJ, Park TS, Choi JR, Park SJ, Cho SY, Jun KR, et al. Submicroscopic deletion of FGFR1 gene is recurrently detected in myeloid and lymphoid neoplasms associated with ZMYM2FGFR1 rearrangements: a case study. Acta Haematol. 2012; $127: 119-23$.

Y. Kim $\cdot$ H. Lee $\cdot$ M. Kim $(\bowtie)$

Department of Laboratory Medicine, College of Medicine,

The Catholic University of Korea, 222 Banpo-daero,

Seocho-gu, Seoul 137-701, Korea

e-mail: microkim@catholic.ac.kr 